\title{
Geochemical and Geophysical Characteristics of the Balud Ophiolitic Complex (BOC), Masbate Island, Philippines: Implications for its Generation, Evolution and Emplacement
}

\author{
Pearlyn C. Manalo ${ }^{1}$, Carla B. Dimalanta ${ }^{1, *}$, Decibel V. Faustino-Eslava ${ }^{2}$, Betchaida D. Payot ${ }^{1}$, \\ Noelynna T. Ramos ${ }^{1}$, Karlo L. Queaño ${ }^{3}$, Americus D. C. Perez ${ }^{4}$, and Graciano P. Yumul Jr. ${ }^{5}$ \\ ${ }^{1}$ Rushurgent Working Group - Tectonics and Geodynamics, National Institute of Geological Sciences, University of the \\ Philippines, Diliman, Quezon City, Philippines \\ ${ }^{2}$ School of Environmental Science and Management, University of the Philippines, Los Baños, Laguna, Philippines \\ ${ }^{3}$ School of Civil, Environmental and Geological Engineeering, Mapua Institute of Technology, Intramuros, Manila, Philippines \\ ${ }^{4}$ Graduate School of Natural Science and Technology, Kanazawa University, Ishikawa, Japan \\ ${ }^{5}$ Apex Mining Co. Inc., Ortigas Center, Pasig City, Philippines
}

Received 4 February 2013, revised 3 January 2014, accepted 19 May 2015

\begin{abstract}
This paper presents the first field, geochemical and geophysical information on the recently recognized Early Cretaceous Balud Ophiolitic Complex (BOC) in the island of Masbate in the Central Philippines. Mapping of the western limb of the island revealed that only the upper crustal section of the BOC is exposed in this area. Geochemically, the pillow basalts are characterized by transitional mid-oceanic ridge basalt-island arc tholeiitic compositions. Gravity surveys yielded low Bouguer anomaly values that are consistent with the highly dismembered nature of the BOC. Short wavelength, high amplitude magnetic anomalies registered across the study area are attributed to shallow magnetic sources. This is taken to support the model that the ophiolitic complex occurs as thin crustal slivers that are not deeply-rooted in the mantle. Comparing BOC with other ophiolites in the Central Philippines, such as those in the islands of Sibuyan, Leyte and Bohol, suggests the possibility of a common or contiguous source for similarly-aged and geochemically composed crust-mantle sequences in the region.
\end{abstract}

Key words: Geochemistry, Geophysics, Balud Ophiolitic Complex, Masbate Island, Philippines

Citation: Manalo, P. C., C. B. Dimalanta, D. V. Faustino-Eslava, B. D. Payot, N. T. Ramos, K. L. Queaño, A. D. C. Perez, and G. P. Yumul Jr., 2015: Geochemical and geophysical characteristics of the Balud Ophiolitic Complex (BOC), Masbate Island, Philippines: Implications for its generation, evolution and emplacement. Terr. Atmos. Ocean. Sci., 26, 687-700, doi: 10.3319/TAO.2015.05.19.01(TC)

\section{INTRODUCTION}

The Philippine archipelago has been and remains to be a complex puzzle for geoscientists trying to reconstruct its geological history. Attempts at formulating a synthesized tectonic reconstruction model are often constrained by insufficient data that are further complicated by active tectonic forces at play (e.g., Pubellier et al. 2004; Dimalanta et al. 2006). Most palinspastic reconstructions available (e.g., Hall 2002; Queaño 2006) considered the Philippine Mobile Belt (PMB) to behave as a single unit. However, the different islands that comprise the PMB exhibit diverse geological characteristics which suggest a wide range of geodynamic histories and present-day conditions.

\footnotetext{
* Corresponding author

E-mail: cbdimalanta@up.edu.ph
}

The Philippines is made up of a collage of continental fragments, island arcs, mélanges, ophiolites, and ophiolitic units. Yumul (2007) classified Philippine ophiolites into four belts based on observed spatial and temporal relationships (Fig. 1a). A general westward younging trend was observed. Belt 1 includes Early to Late Cretaceous ophiolites in the eastern Philippines characterized by complete ophiolite complexes with distinct metamorphic soles. Examples of Belt 1 ophiolites are the Samar Ophiolite, Malitbog Ophiolite and Tacloban Ophiolite. Belt 2 consists of dismembered ultramafic-mafic sequences and mélanges. These early to late Cretaceous ophiolitic sequences are mainly exposed on the western side of the eastern Philippines. This includes ophiolites exposed in the islands of Masbate, Cebu, and Bohol. Ophiolites related to the collision of the PMB 
and the Sundaland-Eurasian margin, dated Eocene to Oligocene, comprise Belt 3. This belt includes the Amnay Ophiolite in Mindoro, the Antique Ophiolite in western Panay and the Sibuyan Ophiolite. Lastly, Belt 4 is comprised of the ophiolite complexes emplaced along continental margins, such as those in Palawan Island. A summary of the geochemical characteristics and age of these units, and their corresponding references is shown in Fig. 1c. Knowledge on the generation, evolution and emplacement of these ophiolite complexes helps us understand the tectonic history of the individual islands and their relationships.

A newly delineated ophiolitic complex is located in southwest Masbate Island, Central Philippines. Other islands comprising this region include Panay, Negros, Cebu, Bohol, Samar, Leyte, Marinduque, and the Romblon Island Group. Most of these islands are underlain by Cretaceous ophiolite and ophiolitic units (Dimalanta et al. 2006). Florendo (1987) suggests the existence of an Early Cretaceous subduction in the Central Philippines followed by back-arc spreading to the east. Recent isotopic ages and geochemical data suggest that the ophiolite and ophiolitic units in the eastern and central Philippines were formed from a single oceanic basin, called the proto-Philippine Sea Plate (e.g., Florendo 1987; Maac and Ylade 1988; Barretto et al. 2000;
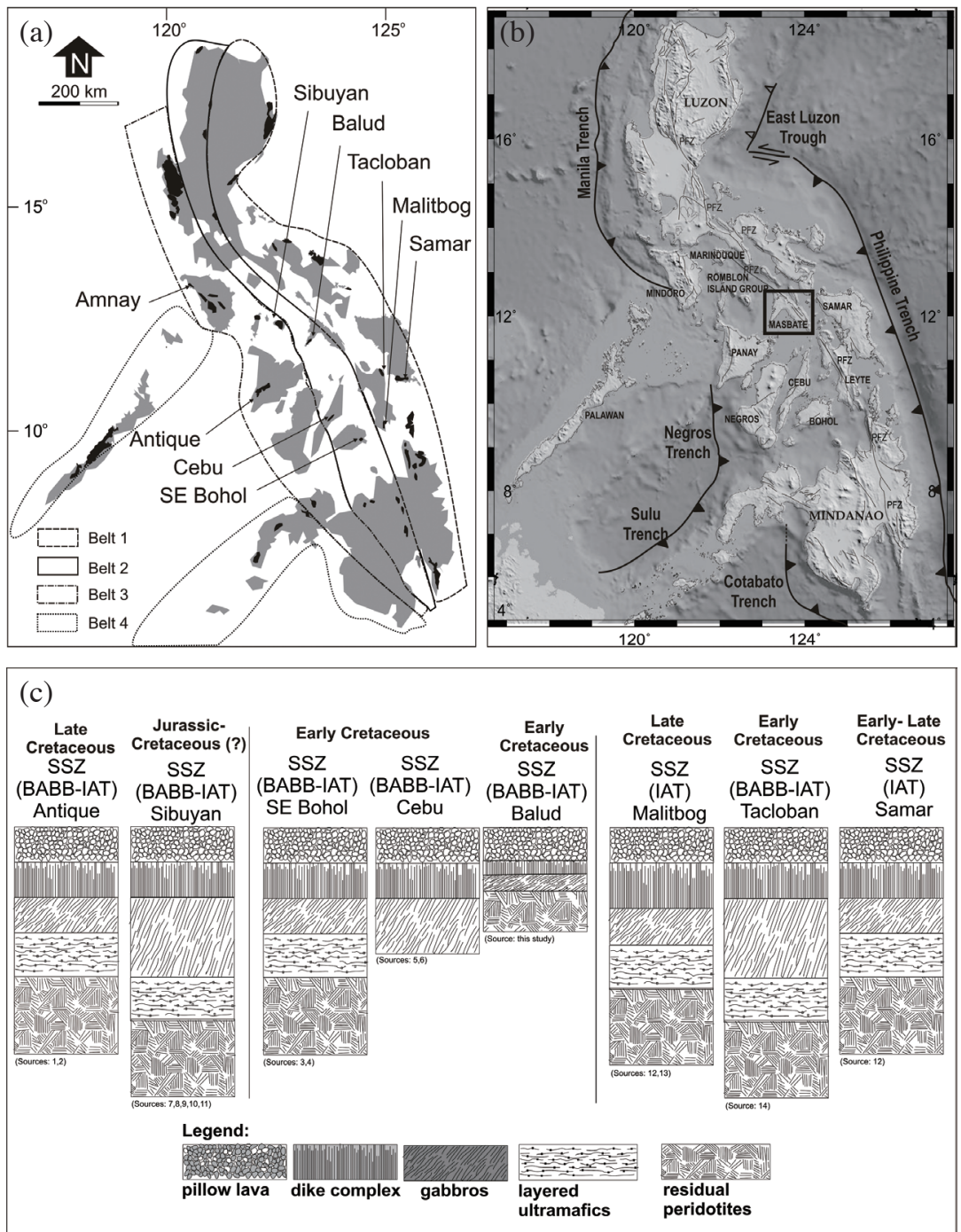

Fig. 1. (a) Classification of Philippine ophiolites based on spatial and temporal relationships (Yumul 2007). Belt 1: regular dashed line; Belt 2: solid line; Belt 3: dashed and dotted line; Belt 4: dotted line. (b) Regional tectonic setting of the Philippines. Oppositely dipping subduction systems bound the Philippine island arc. A left lateral strike-slip fault traverses the archipelago. The study area is highlighted in a box. Active faults of the Philippine Fault Zone (PFZ) are from Tsutsumi and Perez (2010). Topographic and bathymetric data are from the Shuttle Radar Topography Mission (SRTM) (Farr et al. 2007) and National Geophysical Data Center (NGDC) (Amante and Eakins 2009), respectively. (c) General comparison of lithology, age and geochemical characteristics of the ophiolites in the Central Philippines. Numbered references are as follows: (1) Rangin et al. (1991), (2) Tamayo et al. (2001), (3) Barretto et al. (2000), (4) Faustino et al. (2006), (5) Wolcke and Scholz (1988), (6) Hashimoto (1981), (7) Maac and Ylade (1988), (8) Dimalanta et al. (2009), (9) Payot et al. (2009a), (10) Payot et al. (2009b), (11) Payot et al. (2011), (12) Dimalanta et al. (2006), (13) Florendo (1987), (14) Suerte et al. (2005). 
Suerte et al. 2005; Dimalanta et al. 2006).

The delineation of the Balud Ophiolitic Complex (BOC) in southwest Masbate, Central Philippines gives additional information that hopefully would contribute to the reconstruction and understanding of the evolution of the Philippines and this part of Southeast Asia. Geochemical characterization of the volcanic rocks of the ophiolitic complex can give clues to the tectonic setting when the oceanic lithosphere was generated. The geophysical characterization of the present subsurface configuration of the ophiolitic complex hopefully can help in constraining our knowledge on the evolution of the Central Philippines.

\section{REGIONAL GEOLOGIC SETTING}

The Philippines is sandwiched between the Philippine Sea Plate and the Sundaland-Eurasian Plate (e.g., Encarnación 2004; Dimalanta et al. 2009; Yumul et al. 2009; Knittel et al. 2010). It is bound by the discontinuous eastdipping Manila-Negros-Sulu-Cotabato trench system to the west (e.g., Cardwell et al. 1980; Hayes and Lewis 1985; Bautista et al. 2001) and by the East Luzon Trough-Philippine Trench system to the east (Ozawa et al. 2004). Two tectonic regions have been identified: the tectonically-active PMB and the relatively aseismic Palawan microcontinental block. The Pliocene Philippine Fault Zone traverses the archipelago to accommodate the left-lateral component of the oblique convergence of the Philippine Sea plate and the PMB (Quebral et al. 1996; Pubellier and Meresse 2013) (Fig. 1b).

\subsection{Geology of Masbate Island}

Masbate Island is composed of an ophiolitic basement which is unconformably overlain by clastic and non-clastic units (Fig. 2). Sedimentary formations overlying the ophiolitic basement include the Cretaceous Panguiranan Chert, Late Cretaceous Boracay Formation, Eocene Kaal Formation, Late Oligocene Nabangig Formation, Early Miocene Usab Formation, Middle Miocene Lanang Formation, Late Miocene to Early Pliocene Buyag Formation, and the PliocenePleistocene Port Barrera Limestone (Mines and Geosciences Bureau 2004). The Panguiranan Chert is considered to be the sedimentary carapace of the ophiolitic basement. Overlying the Panguiranan Chert is the Boracay Formation, which is composed of polymictic conglomerate with gabbro, basalt and chert clasts set in a sandy matrix. This formation is, in turn, overlain by the andesite and basalt flows of the Kaal Formation. The Nabangig Formation is a bedded sequence of sandstone, mudstone, and polymictic conglomerate capped by a recrystallized limestone. Fine-grained arkosic sandstones and shales are observed to overlie the Nabangig Formation in Barangay Usab, central Masbate. Associations to other lithologic units of adjacent formations cannot be established, thus a new name, the Usab Formation is being proposed. The Lanang Formation overlies the Usab Formation that is composed of a highly deformed, fining upward sequence of conglomerates, lithic sandstones and mudstones. Overlying this is the Buyag Formation, composed of conglomerates with andesite and dacite clasts, shales interbedded with fine siliceous sandstones and siltstone. The youngest sedimentary formation in the area is the coralline Port Barrera Limestone. Nannoplankton assemblages of Porth et al. (1989) report a Pleistocene age for this unit. Paleoenvironmental studies on this unit show that the limestone was formed in an inner to middle shelf environment. Several intrusive bodies are also recognized: Aroroy Quartz Diorite, Mobo Diorite, Lamon Andesite, and Nabongsuran Andesite. The Aroroy Quartz Diorite is a hornblende quartz diorite that intruded the Kaal Formation. Radiometric dating of a quartz diorite sample using K-Ar revealed an age of $38 \mathrm{Ma}$ corresponding to Middle to Late Eocene (MMAJ-JICA 1986a, b). The Mobo Diorite intruded the Nabangig, Usab, and Lanang formations. Radiometric dating suggests an age of 12 Ma corresponding to Middle Miocene (MMAJ-JICA 1990). The Lamon Andesite is a porphyritic andesite occurring as dikes intruded into the Lanang Formation and the Mobo Diorite. A Middle Miocene age (12.2 Ma) was obtained from the $\mathrm{K}$-Ar dating of the andesite porphyry (MMAJ-JICA 1990). The Nabongsuran Andesite is composed of andesitic plugs with dacite facies. Considering that it intrudes the Late Miocene to Early Pliocene Buyag Formation, it is given an age of Early Pliocene.

\section{BOC}

\subsection{Geology}

Considered as the basement unit, the newly delineated BOC is a NE - SW trending fossil oceanic lithosphere located at the western limb of Masbate. Previously described as the Manapao Basalt (Mines and Geosciences Bureau 2004), it is dominated by basaltic rocks that are sometimes pillowed, with subordinate isotropic gabbros and diabase dikes. Outcrops can be found along the coast of Balud town and in Jintotolo Island. This unit had previously been assigned an age of pre-Cretaceous due to its similarity to other basement complexes in the archipelago (MMAJ-JICA 1986a, b).

The pillow basalts are best exposed along the coast from Balud to Calumpang point at the tip of south-western Masbate (Fig. 3a). Generally, the basalts occur either as massive flows or as pillow structures and are moderately weathered and fractured (Fig. 3b). Secondary quartz and calcite veins occupy fractures in the rocks. Chloritization and oxidation are also observed in the pillows. Pillow structures are approximately $0.5-1 \mathrm{~m}$ in diameter and dip towards the NE. Intercalated with the pillow basalts are cherts and siliceous mudstone (Fig. 3c). In transition with the pillow basalts are diabase dikes. These dikes generally trend NW - SE. In some outcrops, the dikes, $1-3 \mathrm{~m}$ wide, cut through basalts 
and gabbros (Fig. 3d). Gabbro exposures are typically massive except when cut by fractures. Some gabbros are silicified, chloritized and pyritized (Fig. 3e).

The Panguiranan Chert is considered as the sedimentary carapace of the BOC.The chert occurs either as beds in some areas or intertongues with the basalt in others. Chert samples that were initially processed for radiolarian extraction revealed the presence of Holocryptocanium sp. cf. $H$. barbui (this work) (Fig. 3f). This is an Aptian to Cenomanian (Early to Late Cretaceous) radiolarian species. Overlying the chert is the Boracay Formation which is made up of conglomerates composed of ophiolitic and chert clasts, siliceous red and green mudstones and siltstones. This was previously reported to be Jurassic in age (MMAJ-JICA 1986a) but in view of the possible Early to Late Cretaceous age obtained for the Panguiranan Chert, this age has to be re-evaluated.

\subsection{Petrography}

The BOC volcanic rocks are mostly aphanitic basalts with some medium-grained dolerites. They exhibit textures
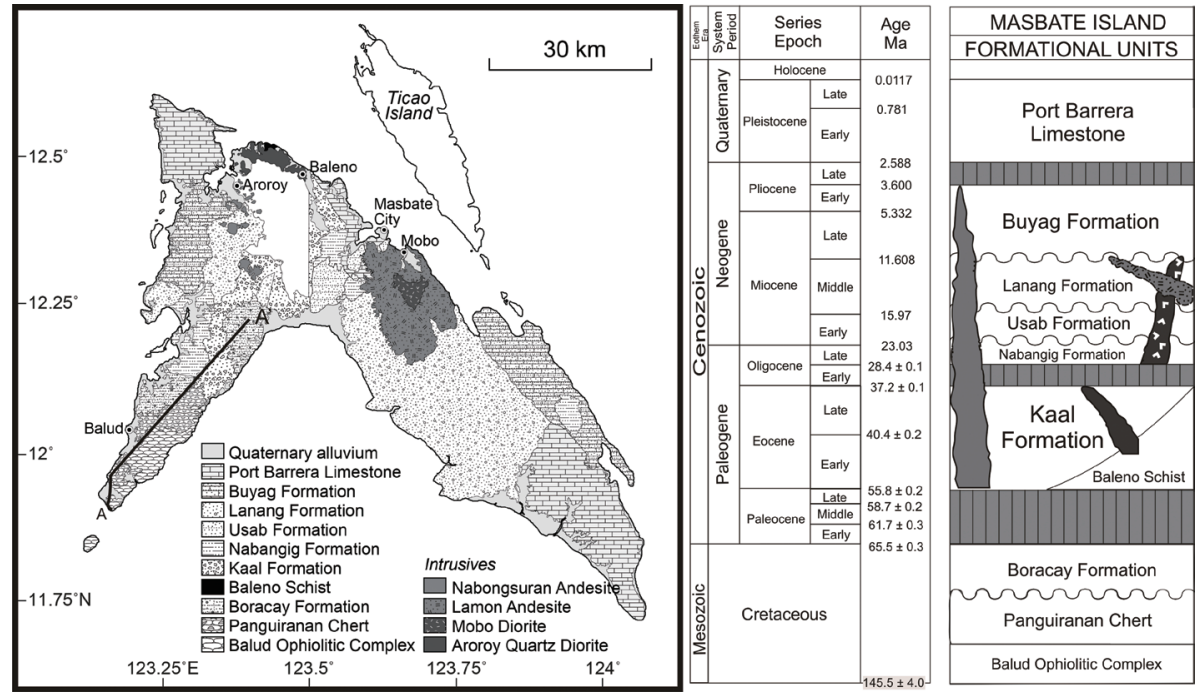

Fig. 2. Geology of Masbate Island. The Balud Ophiolitic Complex (BOC) serves as the island basement. It is overlain by several clastic and nonclastic sedimentary formations. Several intrusive bodies are also recognized in the area. Stratigraphic column is modified from the Mines and Geosciences Bureau (2004). Geophysical survey along line section A - A' was also carried out.
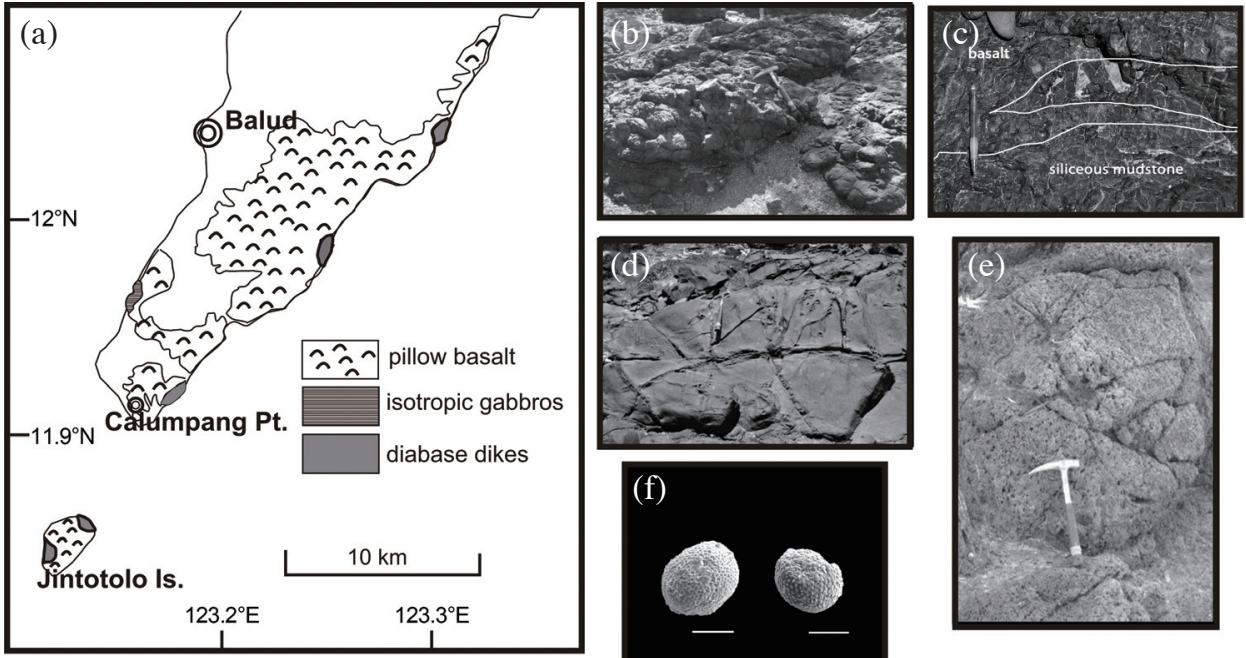

Fig. 3. Geology of BOC. (a) Mapped exposures of basalts, dikes and gabbros. Outcrop photos of (b) BOC pillow basalts. (c) BOC basalt intertonguing with siliceous mudstone. (d) basalt cut by diabase dikes. (e) BOC isotropic gabbro. (f) Holocryptocanium barbui extracted from the Panguiranan chert. White scale bar is $100 \mu \mathrm{m}$. 
that are intergranular, porphyritic and hypidiomorphic. Primary minerals include euhedral to subhedral orthopyroxene, clinopyroxene, and subhedral plagioclase. Pyroxenes are found in the interstices of plagioclase crystals. Acicular laths of calcic plagioclase exhibit polysynthetic twinning. Gabbros collected from east of Balud town also contain minor orthopyroxenes $(<1 \%)$. Hydrothermal alterations of pyroxene to chlorite and plagioclase to sericite are common. Secondary amphiboles are also present and indicate hydrothermal alteration at moderate temperatures, whereas the presence of thin quartz and carbonate veinlets indicate later stage hydrothermal events. Chloritization of the groundmass also developed from the pervasive devitrification of volcanic glasses.

\subsection{Geochemistry}

Representative samples of BOC basaltic rocks were collected from the south and east of the town of Balud and Calumpang Point in south-western Masbate. The samples were prepared at the National Institute of Geological Sciences, University of the Philippines. Samples showing the least degree of weathering were selected for the geochemical analysis. Rocks were cleared of weathered portions before they were powdered using the agate mill. Powdered samples were sent for major element analysis using a PanAnalytical Axios Max X-ray fluorescence (XRF) spectrometer and trace and rare earth element analysis using a Perkin Elmer Elan 9000 inductively-coupled plasma - mass spectrometer (ICP-MS) to the ACME Analytical Laboratories Ltd. in Vancouver, Canada. Results are accurate up to $1 \%$ for major elements and up to $5 \%$ for trace elements.

The BOC basalts are characterized by loss on ignition (LOI) values between $1-3 \mathrm{wt} \%$ that indicate varying but relatively low degrees of alteration. This is likewise supported by petrographic examinations. Their comparatively narrow $\mathrm{SiO}_{2}$ concentrations that range from $46-52 \mathrm{wt} \%$ contrasts with the wide range of $\mathrm{TiO}_{2}$ values $(0.47-2.58 \mathrm{wt} \%)$ (Table 1, Fig. 3). Variation diagrams of major oxides and trace elements (Fig. 4) plotted against $\mathrm{Fe}_{2} \mathrm{O}_{3} / \mathrm{MgO}$ ratios show positive correlation for $\mathrm{Fe}_{2} \mathrm{O}_{3}, \mathrm{TiO}_{2}, \mathrm{P}_{2} \mathrm{O}_{5}, \mathrm{La}, \mathrm{Zr}, \mathrm{Y}$, and $\mathrm{Ce}$ and negative correlation for $\mathrm{SiO}_{2}, \mathrm{Al}_{2} \mathrm{O}_{3}, \mathrm{MnO}, \mathrm{MgO}, \mathrm{CaO}$, and Sr. Scatter plots of $\mathrm{Na}_{2} \mathrm{O}, \mathrm{K}_{2} \mathrm{O}, \mathrm{Ba}, \mathrm{Rb}$, and $\mathrm{K}$ likely indicate remobilization of these relatively mobile elements, hence, their ineffectiveness for geochemical studies. The rare earth elements (REEs) do not appear to have been remobilized significantly as shown by the plots of the total REEs ( $\mathrm{La}+$ $\mathrm{Sm}+\mathrm{Yb}$ ) versus $\mathrm{Y}$ and $\mathrm{TiO}_{2}$ (Figs. 5a, b). The plots show an increase in the total REEs with increasing amounts of $Y$ and $\mathrm{TiO}_{2}$. The $\mathrm{Y}$ and $\mathrm{TiO}_{2}$ are not readily remobilized. Their coherent correlation with the REEs are taken as indicative of the latter not being remobilized (Yumul et al. 2008).

Immobile element ratios ( $\mathrm{Zr} / \mathrm{Ti}$ vs. $\mathrm{Nb} / \mathrm{Y}$ ) show that the Balud samples fall within the basaltic field (Pearce 1996) (Fig. 6a). Based on the Alkalis $\left(\mathrm{Na}_{2} \mathrm{O}+\mathrm{K}_{2} \mathrm{O}\right)-\mathrm{Fe}$ oxides
$\left(\mathrm{FeO}+\mathrm{Fe}_{2} \mathrm{O}_{3}\right)-\mathrm{MgO}(\mathrm{AFM})$ ternary diagram of Irvine and Baragar (1971), BOC samples can be classified as subalkaline tholeiitic basalts (Fig. 6b). This is consistent with the increasing $\mathrm{TiO}_{2}$ and decreasing $\mathrm{MgO}$ and $\mathrm{CaO}$ contents as $\mathrm{FeO}_{\text {total }} / \mathrm{MgO}$ (fractionation index) increases (Fig. 4) (e.g., Faustino et al. 2006).

The eruptive environment of the basalts was determined using different conventional discrimination diagrams. On the V versus Ti diagram of Shervais (1982), the basalts straddle the mid-oceanic ridge and back-arc basin basalt fields (Fig. 6c). The same samples plot within the transitional ocean floor and island arc fields in the ternary Zr-Ti-Y diagram (Pearce and Cann 1973) (Fig. 6d). Normal mid-oceanic ridge-basalt (N-MORB)-normalized (Sun and McDonough 1989) multi-element plots of the BOC basalts show them to mimic the relatively flat N-MORB trends with normalized values very close to 1 . However, strong to very slight depletions in the high field strength elements (HFSEs), particularly $\mathrm{Nb}, \mathrm{Zr}$, and $\mathrm{Ti}$ indicate the influence of subduction components (Fig. 7).

\subsection{Geophysics}

Gravity and magnetic surveys were also carried out on the western limb of the island. Stations occupied simultaneously by gravity and magnetic surveyswere placed $\sim 1-\mathrm{km}$ apart following the national road network. A CG-5 Scintrex Autograv System was used for the gravity survey while a Scintrex EnviMag proton precession magnetometer was employed for the magnetic survey. Magnetic susceptibilities of outcropping rocks were determined using a handheld magnetic susceptibility meter, the KT-9 kappameter. Gravity measurements were corrected to remove variations of the Earth's gravitational field except those due to differences in the density of the underlying rocks. Observed magnetic data were subjected to diurnal and geomagnetic corrections following the methodology of Dimalanta (1996). A SW-NE Bouguer and magnetic anomaly profile was generated over the BOC (Fig. 8).

Observed Bouguer anomalies over the pillow basalts of the BOC range from 20 - 25 mGals. Slightly lower anomalies (15 mGals) were observed over the Panguiranan Chert. The low gravity anomaly of the BOC is comparable to Bouguer anomalies of other dismembered ophiolites such as the Marum ophiolite complex in Papua New Guinea, East Halmahera ophiolite in Indonesia, and the South East Bohol, Cebu and Antique ophiolite complexes in Central Philippines (e.g., Milsom 1984; Milsom et al. 1996; Barretto et al. 2000; Dimalanta et al. 2006). It also suggests that the ophiolite is not deeply rooted in the mantle. Crustal thickness was calculated using the standard formula of Milsom et al. (1996) wherein a 16-mGal Bouguer anomaly corresponds to a 1-km elevation of the Moho depth relative to a standard 30-km thick crust. Based on the resulting Bouguer anomalies, western Masbate 


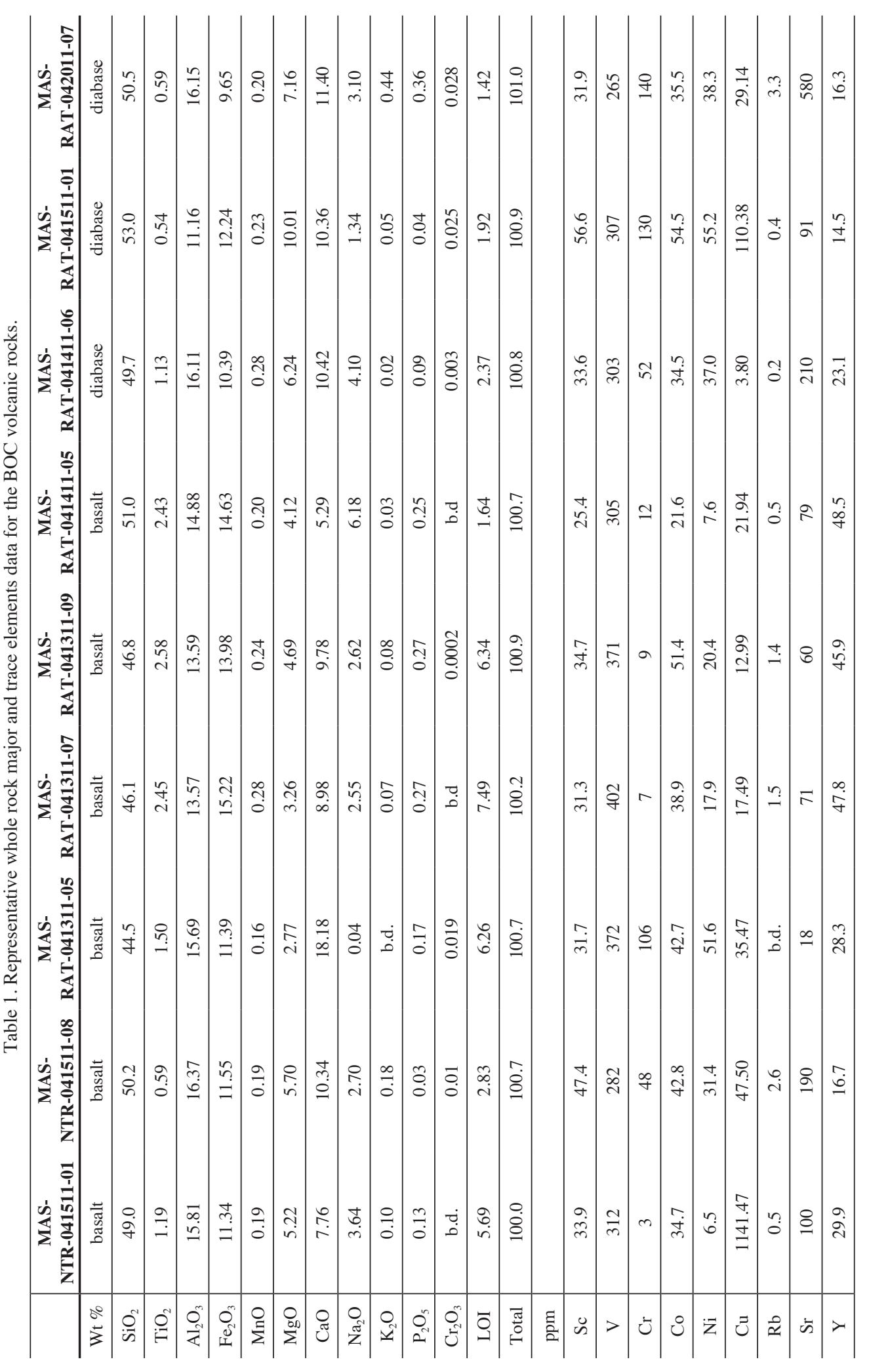




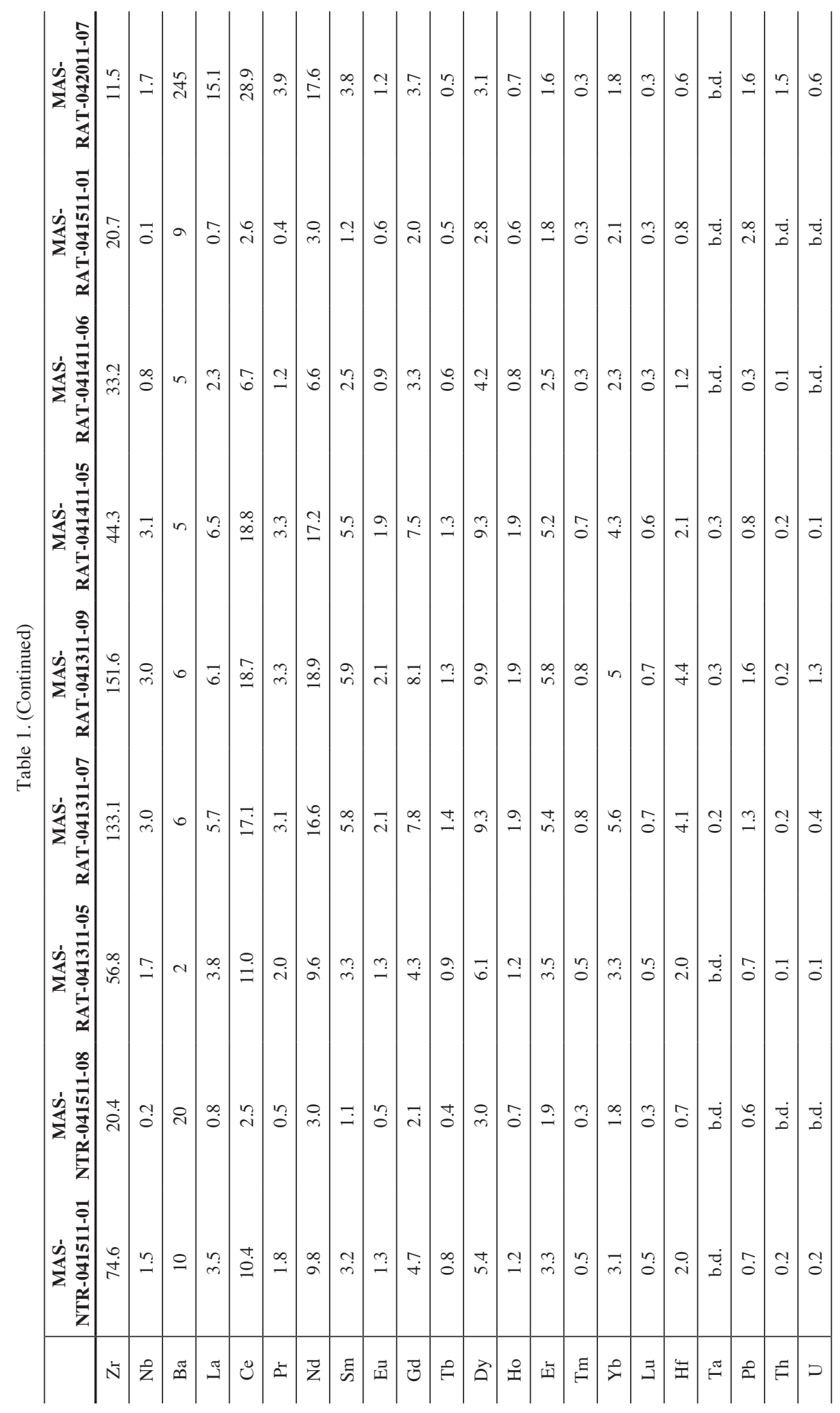



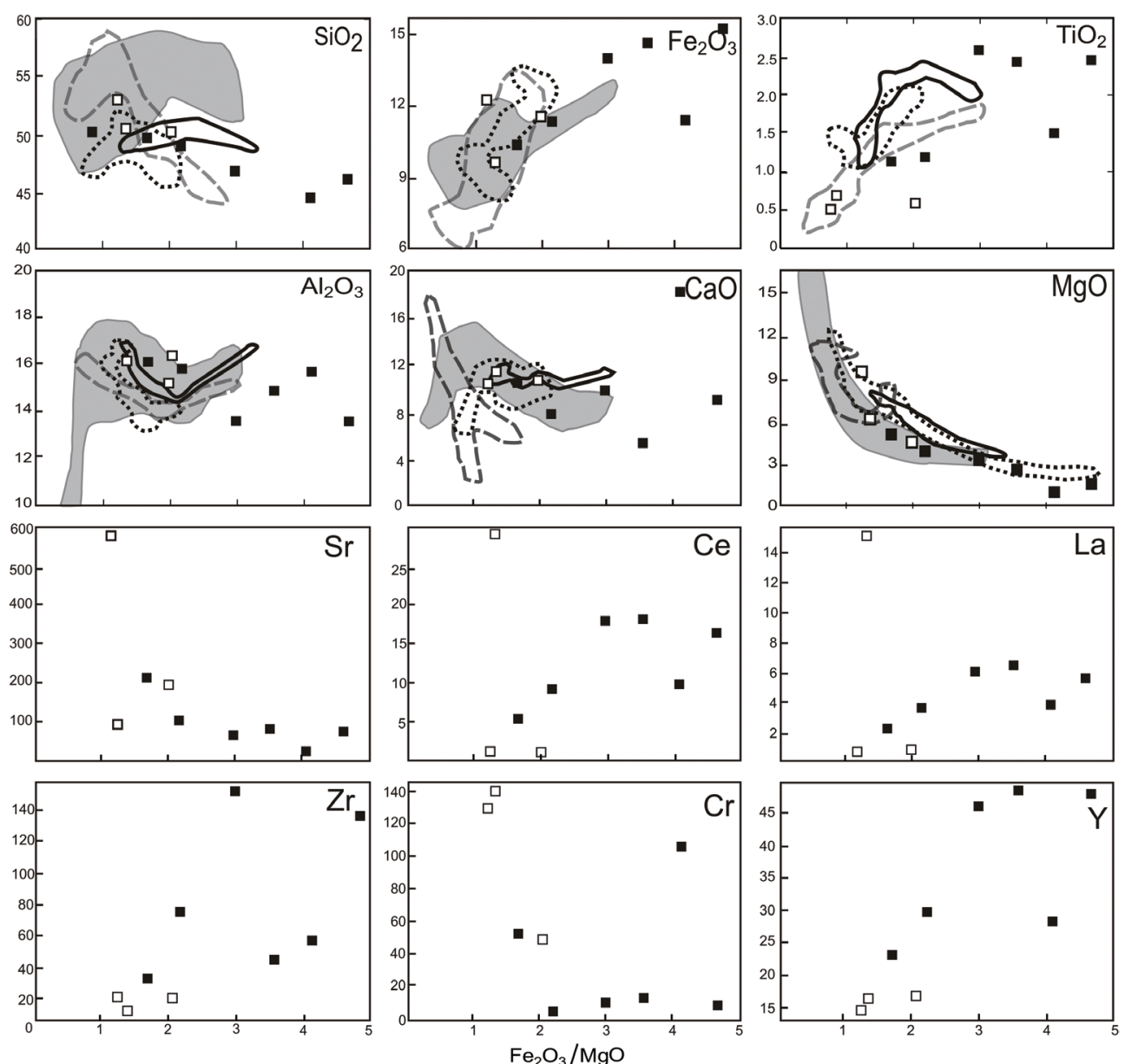

Fig. 4. Variation diagrams of major and trace elements with respect to $\mathrm{Fe}_{2} \mathrm{O}_{3} / \mathrm{MgO}$ as fractionation index. $\mathrm{Positive}$ correlation with $\mathrm{Fe} \mathrm{O}_{3} / \mathrm{MgO}$ is observed for $\mathrm{Fe}_{2} \mathrm{O}_{3}, \mathrm{TiO}_{2}, \mathrm{La}, \mathrm{Zr}$, Y, and Ce. Negative correlation is observed for $\mathrm{SiO}_{2}, \mathrm{Al}_{2} \mathrm{O}_{3}, \mathrm{MgO}, \mathrm{CaO}, \mathrm{Sr}$, and Cr. Basalts are plotted as filled squares, while diabases are plotted as open squares. Defined fields are as follows: solid line - basalts of Amnay Ophiolite Complex (Perez et al. 2013); gray dashed line - basalts of Tacloban Ophiolite Complex (Suerte et al. 2005); black dotted line - volcanic-hypabyssal rocks of Southeast Bohol Ophiolite Complex (Faustino et al. 2006); gray filled area - Lau backarc basin basalts (Hawkins 1977; Falloon et al. 1987).
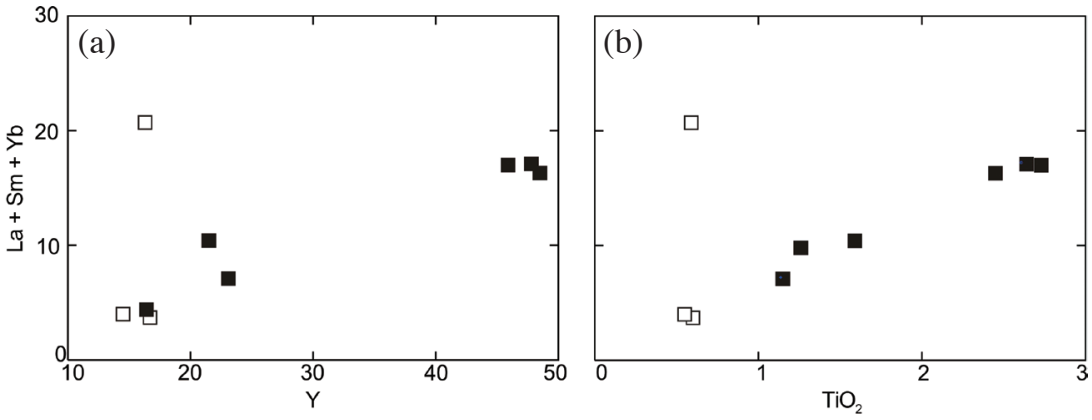

Fig. 5. Plots of $\mathrm{La}+\mathrm{Sm}+\mathrm{Yb}$ versus $\mathrm{TiO}_{2}$ and $\mathrm{La}+\mathrm{Sm}+\mathrm{Yb}$ versus $\mathrm{Y}$ indicate that the rare earth elements of the BOC basalts and diabases have not been significantly remobilized. Sample MAS-RAT-042011-07 which plots away from the general population possibly indicates a mantle source distinct from the rest. Basalts are plotted as filled squares, while diabases are plotted as open squares. See text for discussion. 

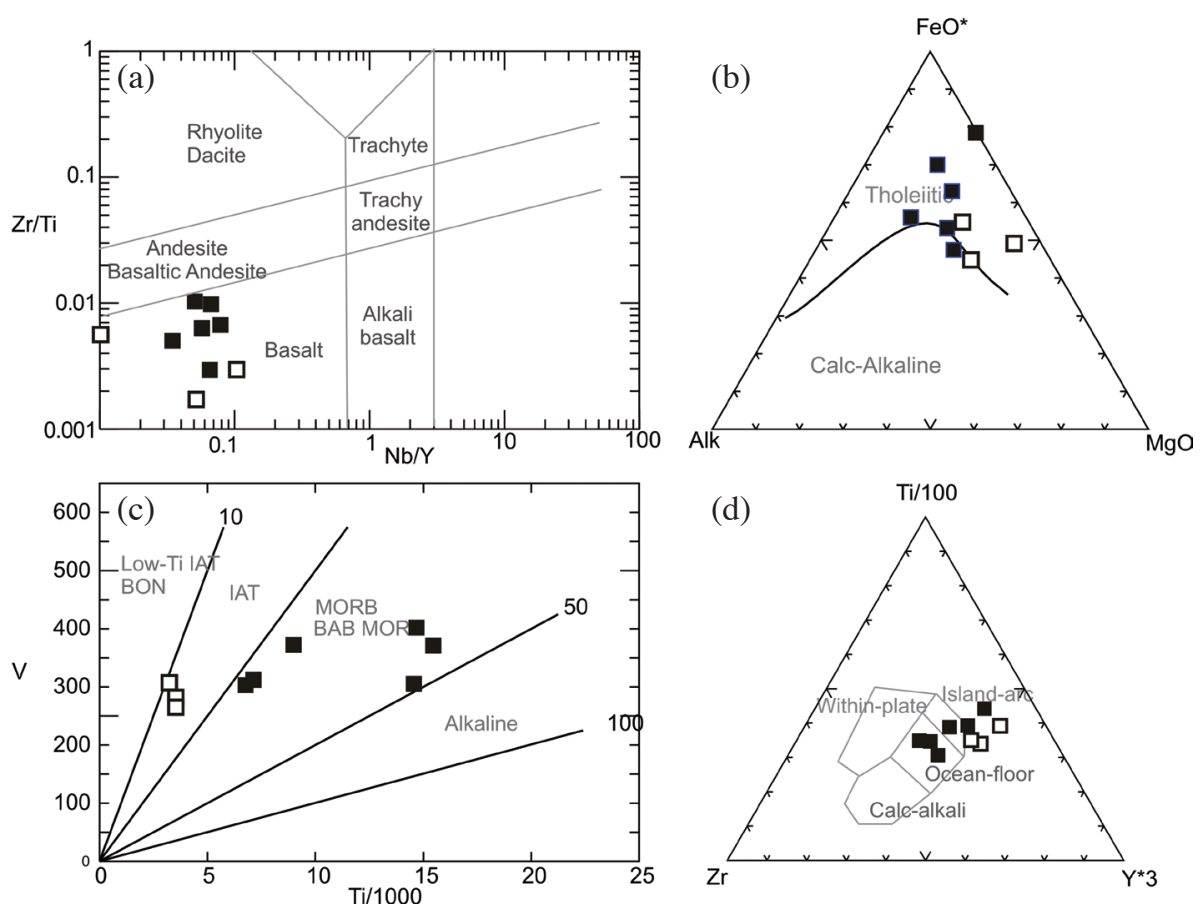

Fig. 6. Discrimination diagrams for the classification of pillow basalts and corresponding tectonic setting of formation. (a) $\mathrm{Alkalis}\left(\mathrm{Na}_{2} \mathrm{O}+\mathrm{K}_{2} \mathrm{O}\right)$ $\mathrm{Fe}$ oxides $\left(\mathrm{FeO}+\mathrm{Fe}_{2} \mathrm{O}_{3}\right)-\mathrm{MgO}(\mathrm{AFM})$ ternary diagram (Irvine and Baragar 1971); (b) $\mathrm{Zr} / \mathrm{Ti}$ vs. Nb/Y diagram (Pearce 1996); (c) Ti-V diagram of Shervais (1982); (d) T-Zr-Y diagram of Pearce and Cann (1973). The BOC volcanic rocks are tholeiitic basalts formed in a transitional mid-oceanic ridge basalt (MORB) - like to island arc environment.

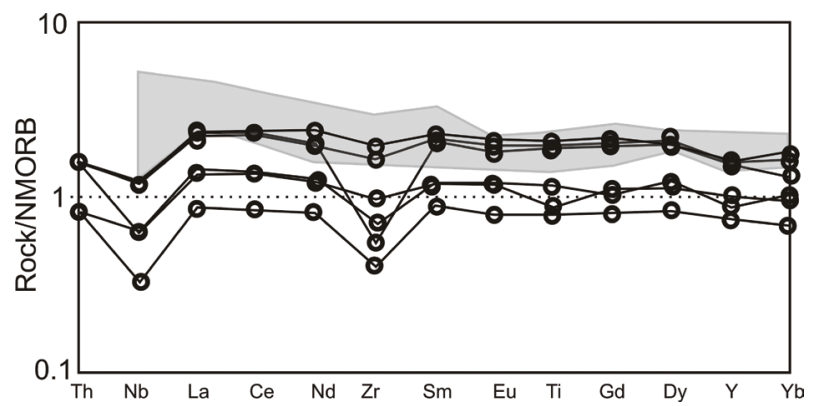

Fig. 7. BOC pillow basalt trace element chemistry. The elements were normalized to N-MORB composition using the Sun and McDonough (1989) values. Moderate to weak depletion in high field strength elements (HFSEs) support the model that subduction affected BOC generation. Multielement field patterns of back-arc basin basalts from Saunders and Tarney (1979) are also plotted for comparison.

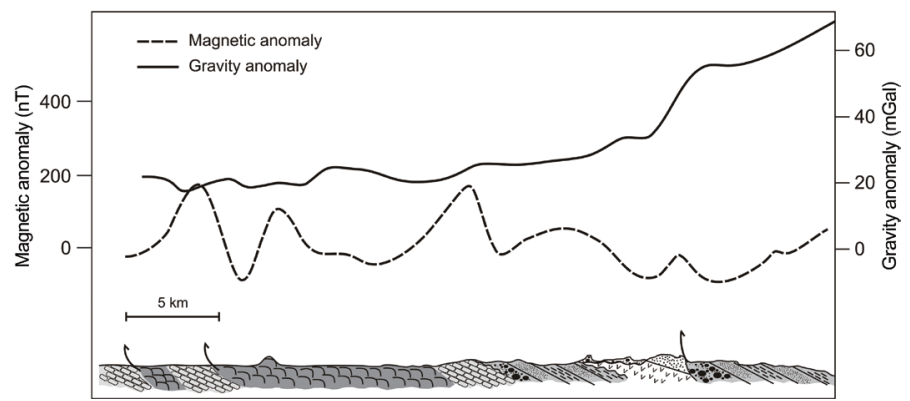

Fig. 8. Gravity and magnetic anomaly profiles over the BOC and overlying sedimentary formations. Observed bouguer anomalies over the pillow basalts range from $20-25$ mGals. Anomalies over the Panguiranan chert is approximately 15 mGals. Increase in Bouguer anomalies is observed over the Boracay Formation. See text for details. 
Island is estimated to be underlain by a $29-\mathrm{km}$ thick crust. This is significantly different from the results derived by Dimalanta and Yumul (2003) who have defined a crustal thickness of $40-50 \mathrm{~km}$ in this area based on limited published seismicity data.

Bouguer anomalies increase to the northeast where the Boracay and Kaal Formations were mapped. This increase in gravity anomaly is attributed to the Boracay Formation lithologic units. Sedimentary rocks are typically characterized by low densities but old sedimentary units display high rock densities (Telford et al. 1976) due to compaction and the infilling of cracks and fractures by secondary minerals. The densities of samples from the Boracay Formation were measured at $\sim 3.2 \mathrm{~g} \mathrm{~cm}^{-3}$. The steep gravity gradient coinciding with the contact between the Boracay and Kaal formations can be attributed to Kaal Formation local volcanic flows casting density contrast against the Boracay Formation sandstones.

The magnetic anomaly profile over the BOC shows two distinct signatures. Short-wavelength high amplitude anomalies were observed over the pillow basalts and chert, while the broad, negative anomalies were observed over the Boracay Formation. The narrow, high amplitude ( 100 to $200 \mathrm{nT}$ ) signatures indicate a shallow magnetic basement, consistent with the outcropping ophiolitic bodies in the area. Magnetic highs ( 200 nT) over chert beds may indicate its magnetic character due to the presence of manganese lenses (e.g., Brown and Evans 1989; Murthy et al. 2009). Broad, negative anomalies (approximately -100 nT) over the Boracay Formation suggest that the sedimentary unit is non-magnetic (e.g., Dimalanta 1996; Sutherland 1999).

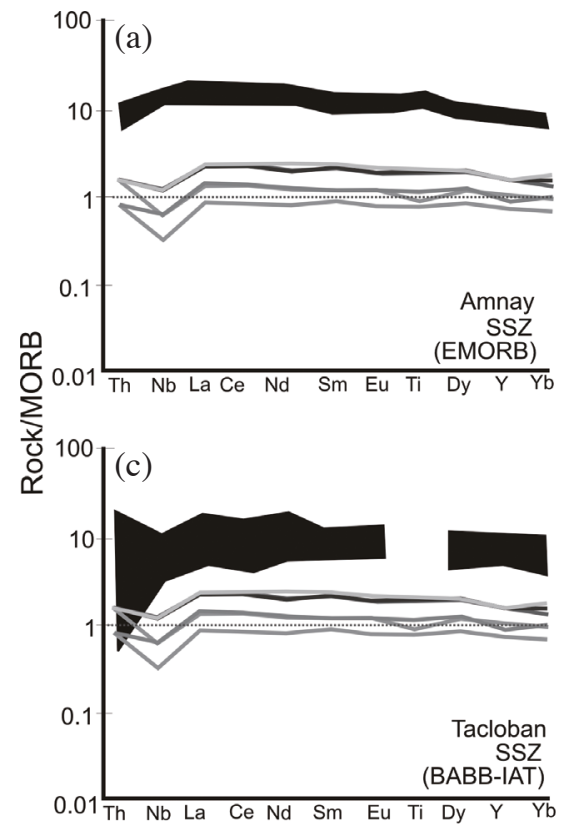

\section{IMPLICATIONS FOR TECTONIC SETTINGS}

Previous works on Central Philippine ophiolites and ophiolitic sequences show these discrete crust-mantle slices to be of supra-subduction affinity [e.g., Tacloban, Samar, Malitbog, Southeast Bohol, Cebu] (e.g., Barretto et al. 2000; Faustino et al. 2003; Tamayo et al. 2004; Suerte et al. 2005; Dimalanta et al. 2006). Apart from the Oligocene Amnay Ophiolite in Mindoro which has the ocean island basalts (OIB) or enriched mid-oceanic ridge basalts (EMORB) component in addition to its transitional island arc tholeiite - N-MORB geochemistry (Jumawan et al. 1998; Perez et al. 2013), the general observation is that ophiolites in the central Philippines were generated with variable degrees of subduction influences (e.g., Yumul 2003; Faustino et al. 2006; Dimalanta et al. 2009; Yumul et al. 2013). The elevated $\mathrm{Th}$ content and negative anomalies in $\mathrm{Nb}, \mathrm{Zr}$, and to a certain extent, $\mathrm{Ti}$, are suggestive of the involvement of sediments and hydrous magmas in the generation of volcanic-hypabyssal BOC rocks (e.g., Pearce 2003; Payot et al. 2011). The ages of these ophiolites, most of which are Mesozoic (e.g., Tamayo et al. 2001; Yumul 2003; Suerte et al. 2005; Dimalanta and Yumul 2006; Zamoras et al. 2008), also allude to their almost contemporaneous generation suggestive of a possible common origin.

The newly recognized BOC clearly falls within range of this petrochemical and temporal variability. Figure 9 compares the BOC geochemical characteristics with other supra-subduction zone ophiolites in the region. The trace and REE signature of the BOC is most similar to those of
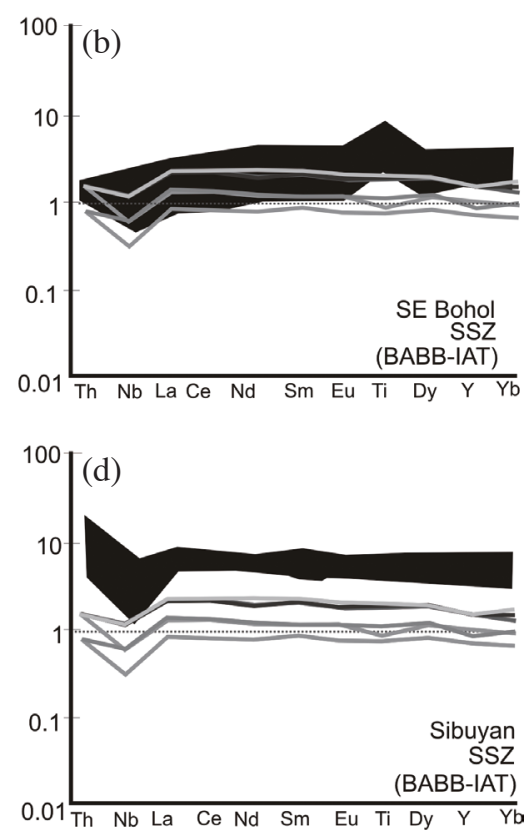

Fig. 9. Comparison of the BOC trace element chemistry (shown as lines) with other ophiolites in the Central Philippines. The BOC clearly differs from the more elevated pattern exhibited by the E-MORB-influenced Amnay ophiolite (a). Similar patterns are observed with Southeast Bohol (b), Tacloban (c), and Sibuyan (d) ophiolites. 
the Southeast Bohol Ophiolite Complex (SEBOC) volcanic rocks in their strong light rare earth elements (LREEs) depletion and flat medium to heavy rare earth element patterns. Similar trends are also noted from the Tacloban and Sibuyan ophiolites, with the exception of their slightly more enriched LREE compared to the BOC. This clearly differs from the more elevated LREE pattern exhibited by the EMORB-influenced Amnay Ophiolite, an emplaced South China Sea (SCS) oceanic crust fragment (e.g., Jumawan et al. 1998; Perez et al. 2013). For that matter, the Oligocene Amnay Ophiolite is a lot younger compared to the Cretaceous BOC indicative of different mantle source origins. Therefore, the BOC, and the rest of the similarly-composed and similarly-aged ophiolites in the region could have originated from a common oceanic crust, other than the SCS.

Based on geophysical observations, most ophiolites in the region are allochthonous and shallow-rooted. Gravity and magnetic investigations show that the SEBOC, Sibuyan and Tacloban ophiolites were emplaced as thin slivers of oceanic crust (e.g., Barretto et al. 2000; Dimalanta et al. 2006, 2009). Their occurrence along the peripheries of islands as highly-dismembered and often poorly-preserved units suggests complex emplacement histories consistent with emplacement along subduction zones. Gravity and magnetic surveys across the BOC reveal that it is also shallow-rooted. Deeper ophiolite members from the lower crust to the mantle are missing from the BOC stratigraphy. Classifiable as a Cordilleran-type ophiolite, this highly-dismembered nature is not different from the general nature of the other Central Philippine ophiolites and ophiolitic complexes (e.g., Moores 1982; Yumul et al. 1997; Dilek 2003).

From studies about SEBOC, the mix of N-MORB, EMORB, boninitic rocks and high-magnesian andesites in the ophiolitic assemblage are taken to indicate emplacement along a forearc margin (Faustino et al. 2006). The same mix of geochemical compositions has not been observed in BOC. Nevertheless, the same emplacement environment can be further explored for this complex, given the similarities between these two ophiolites. Generation in a subductionrelated marginal basin and subsequent emplacement, possibly in a forearc setting, is consistent with the geochemistry and geophysical character of the BOC. Previous works on Mesozoic ophiolites across the Philippines and SE Asia suggested that these similarly aged units represent emplaced fragments of the Proto-Philippine Sea plate (Dimalanta et al. 2006). Resemblance in the geochemical and geophysical characteristics points to the possibility that the BOC also originated from this ancient oceanic lithospheric fragment.

\section{CONCLUSIONS}

The BOC is a dismembered ophiolitic unit, composed mainly of pillow basalts with minor isotropic gabbros and diabase dikes. It is overlain by the Panguiranan Chert which contains radiolarian species of Early to Late Cretaceous age. The volcanic sequence of the BOC shows petrographic and geochemical evidence that it was generated in a supra-subduction zone environment. It is characterized by low Bouguer anomaly values, consistent with signatures of other dismembered ophiolites. The crust in the area is calculated from the gravity data to be $29-\mathrm{km}$ thick. Its magnetic character suggests that it is not presently rooted in the mantle. Geochemically, the BOC basalts are characterized by depletion in HFSEs (e.g., Nb, Ti, Zr) consistent with generation in a subduction environment. These characteristics are fairly akin to most Central Philippine ophiolites that exhibit transitional island arc to mid-ocean ridge geochemical signatures. Being dismembered, it is structurally characterized as a Cordilleran-type oceanic fragment that could have been derived from the proto-Philippine Sea Plate ocean basin.

Acknowledgements The authors acknowledge the logistical and financial support and research grants provided by the Department of Science and Technology through the Philippine Council for Industry, Energy and Emerging Technology Research and Development and the University of the Philippines - National Institute of Geological Sciences (UP-NIGS). Constructive discussions with members of the UP-NIGS Rushurgent Working Group are gratefully acknowledged. Constructive reviews by U. Knittel and another Anonymous Reviewer are appreciated.

\section{REFERENCES}

Amante, C. and B. W. Eakins, 2009: ETOPO1 1 Arc-minute global relief model: Procedures, data sources and analysis. NOAA Technical Memorandum NESDIS NGDC-24, National Geophysical Data Center, Boulder, Colorado, 1-19.

Barretto, J. A. L., C. B. Dimalanta, and G. P. Yumul Jr., 2000: Gravity variations along the Southeast Bohol Ophiolite Complex (SEBOC), Central Philippines: Implications on Ophiolite Emplacement. Isl. Arc, 9, 575583, doi: 10.1111/j.1440-1738.2000.00303.x. [Link]

Bautista, B. C., M. L. P. Bautista, K. Oike, F. T. Wu, and R. S. Punongbayan, 2001: A new insight on the geometry of subducting slabs in northern Luzon, Philippines. Tectonophysics, 339, 279-310, doi: 10.1016/S00401951(01)00120-2. [Link]

Brown, M. J. and A. D. Evans, 1989: Geophysical and Geochemical Investigations of the Manganese Deposits of Rhiw, Western Llyn, North Wales, British Geological Survey Technical Report WF/89/14, BGS Mineral Reconnaissance Programme Report 102.

Cardwell, R. K., B. L. Isaacks, and D. E. Karig, 1980: The spatial distribution of earthquakes, focal mechanism solutions, and subducted lithosphere in the Philippine and Northeastern Indonesian Islands. In: Hayes, D. E. 
(Ed.), The Tectonic and Geologic Evolution of Southeast Asian Seas and Islands, American Geophysical Union, Washington, D. C., doi: 10.1029/GM023p0001. [Link]

Dilek, Y., 2003: Ophiolite concept and its evolution. Spec. Pap. Geol. Soc. Am., 373, 1-16, doi: 10.1130/0-81372373-6.1. [Link]

Dimalanta, C. B., 1996: Magnetic signatures of lithologic variation, fault structures and hydrothermal mineralization: An example from the Baguio Mineral District, Luzon, Philippines. J. Southeast Asian Earth Sci., 14, 1-10, doi: 10.1016/0743-9547(95)00029-1. [Link]

Dimalanta, C. B. and G. P. Yumul Jr., 2003: Magmatic and amagmatic contributions to crustal growth of an island-arc system: The Philippine example. Int. Geol. Rev., 45, 922-935, doi: 10.2747/0020-6814.45.10.922. [Link]

Dimalanta, C. B. and G. P. Yumul Jr., 2006: Magmatic and amagmatic contributions to crustal growth in the Philippine island arc system: Comparison of the Cretaceous and post-Cretaceous periods. Geosci. J., 10, 321-329, doi: 10.1007/BF02910373. [Link]

Dimalanta, C. B., L. O. Suerte, G. P. Yumul Jr., R. A. Tamayo Jr., and E. G. L. Ramos, 2006: A cretaceous supra-subduction oceanic basin source for Central Philippine ophiolitic basement complexes: Geological and geophysical constraints. Geosci. J., 10, 305-320, doi: 10.1007/BF02910372. [Link]

Dimalanta, C. B., E. G. L. Ramos, G. P. Yumul Jr., and H. Bellon, 2009: New features from the Romblon Island Group: Key to understanding the arc-continent collision in Central Philippines. Tectonophysics, 479, 120129, doi: 10.1016/j.tecto.2009.02.015. [Link]

Encarnación, J., 2004: Multiple ophiolite generation preserved in the northern Philippines and the growth of an island arc complex. Tectonophysics, 392, 103-130, doi: 10.1016/j.tecto.2004.04.010. [Link]

Falloon, T. J., D. H. Green, and A. J. Crawford, 1987: Dredged igneous rocks from the northern termination of the Tofua magmatic arc, Tonga and adjacent Lau Basin. Aust. J. Earth Sci., 34, 487-506, doi: 10.1080/08120098708729428. [Link]

Farr, T. G., P. A. Rosen, E. Caro, R. Crippen, R. Duren, S. Hensley, M. Kobrick, M. Paller, E. Rodriguez, L. Roth, D. Seal, S. Shaffer, J. Shimada, J. Umland, M. Werner, M. Oskin, D. Burbank, and D. Alsdorf, 2007: The Shuttle Radar Topography Mission. Rev. Geophys., 45, RG2004, doi: 10.1029/2005RG000183. [Link]

Faustino, D. V., G. P. Yumul, J. V. de Jesus, C. B. Dimalanta, J. C. Aitchison, M. F. Zhou, R. A. Tamayo, and M. M. de Leon, 2003: Geology of southeast Bohol, central Philippines: Accretion and sedimentation in a marginal basin. Aust. J. Earth Sci., 50, 571-583, doi: 10.1046/j.1440-0952.2003.01015.x. [Link]
Faustino, D. V., G. P. Yumul Jr., C. B. Dimalanta, J. V. de Jesus, M. F. Zhou, J. C. Aitchison, and R. A. Tamayo Jr., 2006: Volcanic-hypabyssal rock geochemistry of a subduction-related marginal basin ophiolite: Southeast Bohol Ophiolite-Cansiwang Mélange Complex, Central Philippines. Geosci. J., 10, 291-303, doi: 10.1007/ BF02910371. [Link]

Florendo, F. F., 1987: The tectonic framework and the Cretaceous to Cenozoic evolution of the East-Central Philippines. Master Thesis, University of Tulsa, Oklahoma, USA, $206 \mathrm{pp}$.

Hall, R., 2002: Cenozoic geological and plate tectonic evolution of SE Asia and the SW Pacific: Computer-based reconstructions, model and animations. J. Asian Earth Sci., 20,353-431, doi: 10.1016/S1367-9120(01)000694. [Link]

Hashimoto, W., 1981: Geological development of the Philippines. Geol. Palaeontol. Southeast Asia, 22, 83-170.

Hawkins, J. W., Jr., 1977: Petrologic and geochemical characteristics of marginal basin basalts. In: Talwani, M. and W. C. Pitman III (Eds.), Island Arcs, Deep Sea Trenches and Back-Arc Basins, American Geophysical Union, Washington, D. C., $11 \mathrm{pp}$

Hayes, D. E. and S. D. Lewis, 1985: Structure and tectonics of the Manila trench system, Western Luzon, Philippines. Energy, 10, 263-279, doi: 10.1016/03605442(85)90046-5. [Link]

Irvine, T. N. and W. R. A. Baragar, 1971: A guide to the chemical classification of the common volcanic rocks. Can. J. Earth Sci., 8, 523-548, doi: 10.1139/e71-055. [Link]

Jumawan, F., G. P. Yumul Jr., and R. A. Tamayo Jr., 1998: Using geochemistry as a tool in determining the tectonic setting and mineralization potential of an exposed upper mantle-crust sequence: Example from the Amnay Ophiolitic Complex in Occidental Mindoro, Philippines. J. Geol. Soc. Philippines, 53, 24-48.

Knittel, U., C. H. Hung, T. F. Yang, and Y. Iizuka, 2010: Permian arc magmatism in Mindoro, the Philippines: An early Indosinian event in the Palawan Continental Terrane. Tectonophysics, 493, 113-117, doi: 10.1016/j. tecto.2010.07.007. [Link]

Maac, Y. O. and E. D. Ylade, 1988: Stratigraphic and paleontologic studies of Tablas, Romblon. Report of Research and Development Cooperation ITIT Project No. 8319: Research on stratigraphic correlation of Cenozoic strata in oil and gas fields Philippines, 44-67.

Metal Mining Agency of Japan - Japan International Cooperation Agency (MMAJ-JICA), 1986a: Mineral Deposits and Tectonics of Two Contrasting Geologic Environments in the Republic of the Philippines, Phase II - Masbate area, Northern Leyte area, Southern Leyte, Dinagat, Siargao and Palawan I-IV area, 740 pp.

Metal Mining Agency of Japan - Japan International 
Cooperation Agency (MMAJ-JICA), 1986b: Mineral Deposits and Tectonics of Two Contrasting Geologic Environments in the Republic of the Philippines: Consolidated Report on Masbate, Panay and Romblon Area, 292 pp.

Metal Mining Agency of Japan - Japan International Cooperation Agency (MMAJ-JICA), 1990: Report on the mineral exploration. Mineral Deposits and Tectonics of Two Contrasting Geologic Environments in the Republic of the Philippines, Terminal Report, Japan, 121 pp.

Milsom, J., R. Hall, and T. Padmawidjaja, 1996: Gravity fields in eastern Halmahera and the Bonin Arc: Implications for ophiolite origin and emplacement. Tectonics, 15, 84-93, doi: 10.1029/95TC02353. [Link]

Milsom, J. S., 1984: The gravity field of the Marum ophiolite complex, Papua New Guinea. Spec. Publ. Geol. Soc. Lond., 13, 351-357, doi: 10.1144/GSL. SP.1984.013.01.28. [Link]

Mines and Geosciences Bureau, 2004: Geology of the Philippines, Volume 1: Geology, Department of Environment and Natural Resources, Quezon City, Philippines, $532 \mathrm{pp}$.

Moores, E. M., 1982: Origin and emplacement of ophiolites. Rev. Geophys. Space Phys., 20, 735-760, doi: 10.1029/ RG020i004p00735. [Link]

Murthy, B. V. S., B. Madhusudan Rao, A. K. Dubey, and Srinivasulu, 2009: Geophysical exploration for manganese-some first hand examples from Keonjhar district, Orissa. J. Ind. Geophys. Union, 13, 149-161.

Ozawa, A., T. Tagami, E. L. Listanco, C. B. Arpa, and M. Sudo, 2004: Initiation and propagation of subduction along the Philippine Trench: Evidence from the temporal and spatial distribution of volcanoes. J. Asian Earth Sci., 23, 105-111, doi: 10.1016/S1367-9120(03)001123. [Link]

Payot, B. D., S. Arai, A. Tamura, S. Ishimaru, and R. A. Tamayo Jr., 2009a: Unusual ultra-depleted dunite from Sibuyan Island (the Philippines): A residue for ultradepleted MORB? J. Miner. Petrol. Sci., 104, 383-388, doi: 10.2465/jmps.090620b. [Link]

Payot, B. D., S. Arai, R. A. Tamayo Jr., and G. P. Yumul Jr., 2009b: What underlies the Philippine island arc? Clues from the Calaton Hill, Tablas island, Romblon (Central Philippines). J. Asian Earth Sci., 36, 371-389, doi: 10.1016/j.jseaes.2009.07.001. [Link]

Payot, B. D., S. Arai, and R. A. Tamayo Jr., 2011: Abyssal harzburgite veined by silica-oversaturated melt in the Sibuyan Ultramafics, Romblon, Central Philippines. J. Miner. Petrol. Sci., 106, 175-180, doi: 10.2465/ jmps.101020c. [Link]

Pearce, J. A., 1996: A user's guide to basalt discrimination diagrams. In: Wyman, D. A. (Ed.), Trace Element Geochemistry of Volcanic Rocks: Applications for Massive Sulphide Exploration, Geol. Assoc. Can.
Short Course Notes, Vol. 12, 79-113.

Pearce, J. A., 2003: Supra-subduction zone ophiolites: The search for modern analogues. Spec. Pap. Geol. Soc. Am., 373, 269-293.

Pearce, J. A. and J. R. Cann, 1973: Tectonic setting of basic volcanic rocks determined using trace element analyses. Earth Planet. Sci. Lett., 19, 290-300, doi: 10.1016/0012-821X(73)90129-5. [Link]

Perez, A. D. C., D. V. Faustino-Eslava, G. P. Yumul Jr., C. B. Dimalanta, R. A. Tamayo Jr., T. F. Yang, and M. F. Zhou, 2013: Enriched and depleted characters of the Amnay Ophiolite upper crustal section and the regionally heterogeneous nature of the South China Sea mantle. J. Asian Earth Sci., 65, 107-117, doi: 10.1016/j. jseaes.2012.09.023. [Link]

Porth, H., C. Müller, and C. H. von Daniels, 1989: The sedimentary formations of the Visayan Basin, Philippines. Geol. Jahrbuch Reihe B, 70, 29-87.

Pubellier, M. and F. Meresse, 2013: Phanerozoic growth of Asia: Geodynamic processes and evolution. $J$. Asian Earth Sci., 72, 118-128, doi: 10.1016/j.jseaes.2012.06.013. [Link]

Pubellier, M., C. Monnier, R. Maury, and R. Tamayo, 2004: Plate kinematics, origin and tectonic emplacement of supra-subduction ophiolites in SE Asia. Tectonophysics, 392, 9-36, doi: 10.1016/j.tecto.2004.04.028. [Link]

Queaño, K. L., 2006: Tectonic modeling of Northern Luzon, Philippines and regional implications. Ph.D. Thesis, University of Hong Kong, Hong Kong, 498 pp.

Quebral, R., M. Pubellier, and C. Rangin, 1996: The onset of movement on the Philippine Fault in eastern Mindanao: A transition from a collision to a strike-slip environment. Tectonics, 15, 713-726, doi: 10.1029/95TC00480. [Link]

Rangin, C., J. F. Stephan, J. Butterlin, H. Bellon, C. Müller, J. Chorowicz, and D. Baladad, 1991: Collision néogène d'arcs volcaniques dans le centre des Philippines: Stratigraphie et structure de la chaine d'Antique (île de Panay). Bull. Geol. Soc. Fr., 162, 465-477.

Saunders, A. D. and J. Tarney, 1979: The geochemistry of basalts from a back-arc spreading centre in the East Scotia Sea. Geochim. Cosmochim. Acta, 43, 555-572, doi: 10.1016/0016-7037(79)90165-0. [Link]

Shervais, J. W., 1982: Ti-V plots and the petrogenesis of modern and ophiolitic lavas. Earth Planet. Sci. Lett., 59, 101-118, doi: 10.1016/0012-821X(82)90120-0. [Link]

Suerte, L. O., G. P. Yumul Jr., R. A. Tamayo Jr., C. B. Dimalanta, M. F. Zhou, R. C. Maury, M. Polvé, and C. L. Balce, 2005: Geology, geochemistry and U-Pb SHRIMP age of the Tacloban Ophiolite Complex, Leyte Island (Central Philippines): Implications for the existence and extent of the proto-Philippine Sea 
Plate. Resour. Geol., 55, 207-216, doi: 10.1111/j.17513928.2005.tb00242.x. [Link]

Sun, S. S. and W. F. McDonough, 1989: Chemical and isotopic systematics of oceanic basalts: Implications for mantle composition and processes. Spec. Publ. Geol. Soc. Lond., 42, 313-345, doi: 10.1144/GSL. SP.1989.042.01.19. [Link]

Sutherland, R., 1999: Basement geology and tectonic development of the greater New Zealand region: An interpretation from regional magnetic data. Tectonophysics, 308, 341-362, doi: 10.1016/S0040-1951(99)00108-0. [Link]

Tamayo, R. A., Jr., G. P. Yumul Jr., R. C. Maury, M. Polvé, J. Cotten, and M. Bohn, 2001: Petrochemical investigation of the Antique Ophiolite (Philippines): Implications on volcanogenic massive sulfide and podiform chromitite deposits. Resour. Geol., 51, 145-164, doi: 10.1111/j.1751-3928.2001.tb00088.x. [Link]

Tamayo, R. A., Jr., R. C. Maury, G. P. Yumul Jr., M. Polvé, J. Cotten, C. B. Dimantala, and F. O. Olaguera, 2004: Subduction-related magmatic imprint of most Philippine ophiolites: Implications on the early geodynamic evolution of the Philippine archipelago. Bull. Geol. Soc. Fr., 175, 443-460, doi: 10.2113/175.5.443. [Link]

Telford, W. M., L. P. Geldart, R. E. Sheriff, and D. A. Keys, 1976: Applied Geophysics, Cambridge University Press, $877 \mathrm{pp}$.

Tsutsumi, H. and J. S. Perez, 2010: Large-scale digital mapping of the Philippine fault zone based on aerial photograph interpretation. Proceedings of the Symposium on Hokudan International Symposium on Active Faulting, Awaji City, Hyogo, Japan, 101-102.

Wolcke, F. and J. Scholz, 1988: Über die paläobiogeographische Bedeutung eines Vorkommens caprinider Rudisten aus der Unterkreide von Cebu (Philippinen). Mitteilungen aus dem Geologisch-Paläontologischen Institut der Universität Hamburg, 67, 121-133.
Yumul, G. P., Jr., 2003: The Cretaceous Southeast Bohol Ophiolite Complex, Central Philippines: A highly disaggregated supra-subduction zone ophiolite. J. Asian Earth Sci., 21, 957-965, doi: 10.1016/S13679120(02)00086-X. [Link]

Yumul, G. P., Jr., 2007: Westward younging disposition of Philippine ophiolites and its implication for arc evolution. Isl. Arc, 16, 306-317, doi: 10.1111/j.14401738.2007.00573.x. [Link]

Yumul, G. P., Jr. , G. R. Balce, C. B. Dimalanta, and R. T. Datuin, 1997: Distribution, geochemistry and mineralization potentials of Philippine ophiolite and ophiolitic sequences. Ofioliti, 22, 47-56.

Yumul, G. P., Jr., M. F. Zhou, C. Y. Wang, T. P. Zhao, and C. B. Dimalanta, 2008: Geology and geochemistry of the Shuanggou ophiolite (Ailao Shan ophiolitic belt), Yunnan Province, SW China: Evidence for a slowspreading oceanic basin origin. J. Asian Earth Sci., 32, 385-395, doi: 10.1016/j.jseaes.2007.11.007. [Link]

Yumul, G. P., Jr., C. B. Dimalanta, E. J. Marquez, and K. L. Queaño, 2009: Onland signatures of the Palawan microcontinental block and Philippine mobile belt collision and crustal growth process: A review. J. Asian Earth Sci., 34, 610-623, doi: 10.1016/j.jseaes.2008.10.002. [Link]

Yumul, G. P., Jr., C. B. Dimalanta, R. A. Tamayo Jr., and D. V. Faustino-Eslava, 2013: Geological features of a collision zone marker: The Antique Ophiolite Complex (Western Panay, Philippines). J. Asian Earth Sci., 65, 53-63, doi: 10.1016/j.jseaes.2012.08.017. [Link]

Zamoras, L. R., M. G. A. Montes, K. L. Queaño, E. J. Marquez, C. B. Dimalanta, J. A. S. Gabo, and G. P. Yumul Jr., 2008: Buruanga peninsula and Antique Range: Two contrasting terranes in Northwest Panay, Philippines featuring an arc-continent collision zone. Isl. Arc, 17, 443-457, doi: 10.1111/j.1440-1738.2008.00645.x. [Link] 